\title{
A TEST FOR THE DETECTION OF CYTOTOXIC ANTIBODIES TO SPERMATOZOA IN MAN
}

\author{
J. HAMERLYNCK AND PH. RÜMKE \\ The Netherlands Cancer Institute, Department of Immunology, \\ Amsterdam, The Netherlands \\ (Received 1st April 1968)
}

It is known from experiments with male rodents that no causal relationship exists between the titre of certain circulating (complement fixing and immobilizing) antibodies and the degree of testicular damage in induced autoimmune orchitis (Freund, Lipton \& Thompson, 1953; Bishop, Narbaitz \& Lessof, 1961; Chutná \& Rychlikova, 1964a). Cytotoxic antibodies, however, seem to play an important role in the development of experimental autoimmune orchitis (Chutná \& Rychlikova, 1964b; Voisin, personal communication).

To investigate whether naturally occurring auto-immune orchitis does exist in man it is, therefore, more important to examine sera of patients with testicular disorders and other conditions for the presence of cytotoxic antibodies to spermatozoa rather than for any other circulating antibody, such as spermagglutinins which, as revealed by testis biopsies, have been shown to be present in sera of patients with normal spermatogenesis (Rümke \& Hellinga, 1959). For the detection of cytotoxic antibodies to spermatozoa we have employed a modification of a cytotoxic test for leucocyte antibodies (Engelfriet \& Britton, 1965). Cytotoxicity was determined by the uptake of trypan blue by the damaged cells.

This report is concerned chiefly with the technical problems of the test, although some preliminary results are also mentioned.

Donor semen samples with good motility and sperm count around $10^{8} / \mathrm{m}$ were diluted $1: 10$ in phosphate buffered saline ( $\mathrm{pH} \mathrm{7.4)}$ and centrifuged at $500 \mathrm{rev} / \mathrm{min}$ for $30 \mathrm{~min}$. The sediment was re-suspended in buffered saline up to a concentration around $10^{8}$ spermatozoa $/ \mathrm{ml}$.

All sera were heated at $56^{\circ} \mathrm{C}$ during $30 \mathrm{~min}$ before use to destroy complement activity. As a source of complement fresh human $\mathrm{AB}$ serum was used.

A $1 \%$ trypan blue solution of isotonic ionic strength was obtained by adding one volume of saline $(\mathrm{NaCl} 0.9 \%$ ) to one volume of $2 \%$ trypan blue (British Drug Houses) solution boiled in distilled water.

One drop of sperm suspension, one drop of serum and two drops of complement were mixed in a test tube and incubated at $37^{\circ} \mathrm{C}$. To this mixture two more drops of complement were added after 30 and 60 min of incubation. After a total incubation of 90 min one drop of trypan blue solution was added and the mixture was incubated again for $60 \mathrm{~min}$ at $37^{\circ} \mathrm{C}$. This was followed by centrifugation at $500 \mathrm{rev} / \mathrm{min}$ for $30 \mathrm{~min}$. The sediment was then sucked into 
a capillary and smeared over the slide; the smear was air-fixed and ready for microscopical examination.

The spermatozoa that remained alive were visible, being unstained and luminous, whereas the spermatozoa that were already dead or killed during incubation were blue-coloured. Spermatozoa with only a trace of blue were considered as dead.

Since the varying number of already dead spermatozoa in the donor sample makes comparison between the different tests rather difficult, sufficient spermatozoa were counted in the negative standard smear (preparation made concurrently with experimental smear) as was necessary to find 100 unstained cells among them. Thus, the total number of cells counted in the negative smear equals 100 unstained cells + a certain number of stained dead cells $(d)$. An exactly similar total number of cells was also counted for the experimental smears. If, in the experimental serum, the total number of unstained cells $(x)$ is less than 100, then $100-x$ cells were judged to have been killed by the cytotoxic activity of the serum. This figure was called the spermatotoxic index (STI).

A statistical analysis of variance was based upon results with normal sera (variation in one smear, variation within several preparations of one serum, variation within normal sera). It could be concluded that STIs over 25 are significantly positive $(P=0 \cdot 01)$. However, to obtain this statistical significance limit, a varying number of countings in the negative standard smear depending on the number of dead cells $(d)$ is necessary: in case $d=50$, mediation of three countings in the negative standard smear is sufficient; mediation of eight countings, however, is necessary in case $d=300$; the number of countings that will have to be carried out in the standard smear is found by applying the formula:

$$
n=2 \frac{100+d}{100}
$$

In the test smears one counting is sufficient.

Since the STI under 25 lies within the variance of the test but cannot be considered as negative, we made a restriction for the results between 15 and 25 which we called dubious or weakly positive: replicates with these sera can eliminate the truly negative sera from this group.

Since cytotoxic antibodies are complement dependent, the test was repeated with the positive sera in the absence of complement to be sure that the spermatotoxic activity of these sera was due to antibodies and not due to any other possible cytotoxic non-complement-dependent substance in the serum. For this purpose, inactivated $\left(56^{\circ} \mathrm{C}, 30 \mathrm{~min}\right) \mathrm{AB}$ serum was used instead of fresh $\mathrm{AB}$ serum. In this control test none of the sera turned out to be positive.

Several individual positive sera were tested with various sperm samples. Preliminary results indicate that various sperm samples do not significantly influence the outcome of the test.

In order to determine whether a normal STI could be found in cases where no antibodies were expected, the sera of ten young fathers and seventy old nuns were tested. In no case did the STI pass the statistical significance limit. 
The next step was to test spermagglutinating sera from infertile males. Thirty-five sera, with various spermagglutinin titres, were tested (Text-fig. 1) and a fair correlation existed between these titres and the STI. Text-fig. 1 shows also that some of the spermagglutinating sera have no spermatotoxic activity at all. It would thus be interesting to compare clinical and spermatological findings in patients with spermagglutinins with and without spermatotoxic antibodies. In eight patients without and in six patients with spermatotoxic antibodies in their serum (Table 1) clinical data were available from one

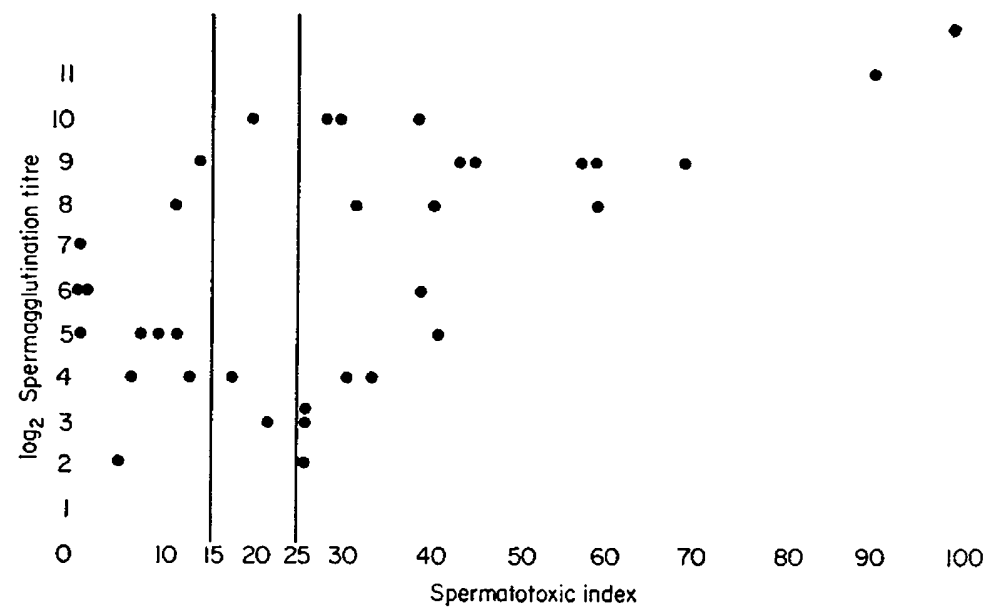

TeXT-FIG. 1. Correlation of spermatotoxic index with spermagglutination titre in infertile patients.

TABLE 1

SPERMAGGLUTINATING SERA FROM INFERTILE MALES WITHOUT AND WITH SPERMATOTOXIC ANTIBODIES

\begin{tabular}{l|c|c}
\hline & Without & With \\
\cline { 2 - 3 } Total & 8 & 6 \\
Spermagglutination titres & 4 to 256 & 4 to 256 \\
(Mean log 2) & $(5 \cdot 4)$ & $(4 \cdot 7)$ \\
Oligozoospermia & 3 & 5 \\
Asthenozoospermia & 5 & 6 \\
Small testicles & 2 & 5 \\
\hline
\end{tabular}

observer who was not informed about the serological results. Both groups had comparable spermagglutinin titres. As shown in Table 1, a tendency of correlation seems to exist between the presence of spermatotoxic antibodies and oligozoospermia, asthenozoospermia and small testicles. Larger series are, however, necessary to establish whether this correlation is real.

Sera of seventy-nine patients were tested in whom, during the past 4 years, a testis biopsy was performed and in whom the testis histology was found to be in some way pathological. Nine sera were significantly positive, eight sera were dubious or weakly positive. Three positive sera also possessed spermagglutinins. 
These observations made clear that cytotoxic antibodies can occur independently of the presence of spermagglutinins and are consistent with the hypothesis that in some instances of idiopathic testicular degeneration an auto-immune process might be involved.

This investigation received financial support from the World Health Organization.

The authors thank Miss Nanda van Amstel for her faithful and skilful technical assistance. Thanks are expressed to Dr G. Hellinga and Dr J. Kremer for their kind co-operation.

\section{REFERENCES}

Bishop, D. W., Narbaitz, R. \& Lessof, M. (1961) Induced aspermatogenesis in adult guinea pigs injected with testicular antigen and adjuvant in neonatal stages. Devl Biol. 3, 444.

ChutnA, J. \& Rychlikova, M. (1964a) A study of the biological effectiveness of antibodies in the development and prevention of experimental autoimmune aspermatogenesis. Folia biol. 10, 188.

Chutná, J. \& Rychlikova, M. (1964b) Prevention and suppression of experimental autoimmune aspermatogenesis in adult guinea pigs. Folia biol. 10, 177.

Engelfriet, C. P. \& Britton, A. (1965) A cytotoxic test for leucocyte antibodies. Vox Sang. 10, 660.

FReUnd, J., Lipton, M. M. \& Thompson, G. E. (1953) Aspermatogenesis in the guinea pig induced by testicular tissue and adjuvants. $\mathcal{F}$. $\exp$. Med. $97,71$.

Rümke, Ph. \& Hellinga, G. (1959) Autoantibodies against spermatozoa in sterile men. Am. F. clin. Path. 32, 357. 